\title{
Enzymatic Oxidative Stress Indicators and Oxidative Stress Index in Patients of Leprosy
}

\author{
Raka I', Rastogi MK' ${ }^{1}$, Gahalaut $\mathrm{P}^{1}$, Kaur J², Mishra $\mathbf{N}^{1}$ \\ ${ }^{1}$ Department of Dermatology Venereology and Leprology; ${ }^{2}$ Department of Biochemistry, Shri Ram Murti Smarak Institute \\ of Medical Sciences, Bareilly (U.P)
}

\begin{abstract}
Introduction: Leprosy is a chronic granulomatous disease caused by Mycobacterium leprae. Oxidative stress caused by Reactive oxygen species (ROS) plays a crucial role in the pathogenesisis of leprosy.

Objective: To measure the enzymatic oxidative stress indicators and oxidative stress index in patients of leprosy and compare them with healthy age \& sex matched controls.

Materials and Methods: In this prospective study 30 untreated leprosy patients were included in the study and matched with 60 healthy controls. Biochemistry estimation was done with blood samples and MDA (lipid peroxidation), Nitric oxide (NO), (SOD) Superoxide dismutase (antioxidant enzyme), total oxidant status (TOS), total antioxidant status(TAS) and oxidative stress index (OSI) were estimated.

Results: Highly significant rise $(p<0.0001)$ in serum MDA, NO, TOS and OSI was seen in leprosy patients when compared with controls with highly significant decline in SOD and TAS.

Conclusion: The study confirms the oxidative stress in leprosy and suggests antioxidant therapy may be used as an adjuvant in the treatment of leprosy along with MDT.

Key words: Lipid peroxidation; Mycobacterium leprae; oxidants; reactive oxygen species; superoxide dismutase
\end{abstract}

\section{Introduction}

eprosy (Hansen's disease) is a chronic, Lranulomatous, mutilating, visible, ancient, stigmatizing disease caused by Mycobacterium leprae and clinically manifests as nodules, plaques, thickened dermis and peripheral nerves. ${ }^{1}$

Oxidative stress (OS) caused by Reactive oxygen species (ROS) plays a crucial role in the pathogenesisis of leprosy. ${ }^{2}$ OS is defined as excessive generation of ROS. ${ }^{3}$ Normally the antioxidant defense system is responsible for balancing the production of ROS but in leprosy the production of ROS exceeds the normal limits resulting in OS causing further insult to cells, tissue and biomolecules. ${ }^{3}$ Experimental studies support the possible relation between ROS and leprosy. ${ }^{4}$

\footnotetext{
Address of Correspondence:

Dr. Madhur Kant Rastogi

Assistant Professor

Department of Dermatology, Venereology and Leprology

Shri Ram Murti Smarak Institute of Medical Sciences, Bareilly (U.P), India.

E-mail:kantmadhur@gmail.com
}

The 'antioxidant defense system' comprises of enzymatic scavangers of ROS, like SOD (Superoxide dismutase), catalase and glutathione peroxidise and nonenzymatic antioxidants like vitamin E, C and glutathione. ${ }^{3}$ This dynamic defense system removes the aggressive oxygen species and keeps the concentration of ROS at normal levels. ${ }^{3}$

ROS have only transient existence and cannot be measured directly in vitro; hence the end products of OS are used as laboratory markers. ${ }^{5}$ Among the

Submitted: $11^{\text {th }}$ November 2017

Accepted: $15^{\text {th }}$ January 2018

Published: $21^{\text {st }}$ March 2018

How to cite this article

Raka I, Rastogi MK, Gahalaut P, Kaur J, Mishra N. Enzymatic oxidative stress indicators and oxidative stress index in patients of leprosy. Nepal Journal of Dermatology Venereology and Leprology. 2018;16(1):35-40. doi: http://dx.doi.org/10.3126/ njdvl.v16i1.19402

\section{(c) (i)}

Licensed under CC BY 4.0 International License which permits use, distribution and reproduction in any medium, provided the original work is properly cited. 
biomarkers of OS, Lipid peroxidation (LPO) and Protein carbonylation are the most frequently used reliable laboratory parameters. ${ }^{5}$ Measurement of serum antioxidants is another way to investigate OS. ${ }^{6}$ SOD catalyzes the dismutation of superoxide ion into oxygen and hydrogen peroxide and is considered most reliable to determine enzymatic OS. ${ }^{6}$ The present study was aimed to analyze the relationship between OS indices, and enzymatic OS indicators in leprosy cases and to find out whether these changes have a significant association with bacterial load and type of leprosy.

\section{Recruitment of patients and controls:}

In this prospective study, conducted in a tertiary care centre of North India, newly diagnosed adult leprosy patients registered in leprosy clinic from July 2014 to December 2015 were included based on below mentioned inclusion and exclusion criterion. The study was approved by the Institutional ethical committee and is registered in CTRI (CTRI/2017/08/009369). Newly diagnosed leprosy patients before the start of anti-leprosy treatment, were selected as cases. The patients were categorized according to the WHO classification based on clinical, histological and bacteriological criteria. ${ }^{8}$ Clinical details included the number and distribution of lesions, pattern of nerve involvement, and complications including reactions, neuritis and deformities. The patients who were in reactions, taking any form of antioxidant/multivitamin supplementation, giving history of any other infectious diseases or other major systemic illnesses were excluded from the study. The Controls were age and sex matched and were apparently healthy individuals on general physical examination and without any past history of any chronic disease or leprosy. Above mentioned exclusion criteria for cases were also applied for controls. Persons with history of any addiction like smoking or alcoholic habits and other chronic skin or systemic diseases like diabetes mellitus, cancer or hypertension were also excluded from the study.

After initial screening according to the inclusion and exclusion criteria of all the patients, 60 were deemed fit for the inclusion in the study. Informed and written consent were taken from the patients for inclusion in the study. Out of 60 , only 30 patients gave the consent for inclusion in the study. Blood sample was collected from 60 age and sex matched healthy controls and 30 leprosy Patients constituted the study groups.

\section{Materials and Methods}

Five $\mathrm{ml}$ blood was drawn from median cubital vein of the patients into plain tubes. To separate the serum from the plasma sample, it was centrifuged at $5000 \times$ $g$ for $5 \mathrm{~min}$ at room temperature. All serum samples were stored at $-20^{\circ} \mathrm{C}$ until time of processing.

Lipid peroxidation was measured by the quantification of MDA (Malondialdehyde) in blood samples of patients using the thiobarbituric acid-reactive substances (TBARS) assay. ${ }^{8}$ NO (Nitric oxide) was evaluated based on the principle that nitrate (NO3-) present in the serum samples is reduced to nitrite using nitrate reductase and the method is known as Griess Method. ${ }^{9}$ Measurement of total oxidant status (TOS) was based on principle that oxidant present in the sample oxidizes the ferrous ion-o-dianisidine complex to ferric ions. The oxidation reaction is enhanced by glycerol molecules, which are enormously present in the reaction medium. During this oxidation reaction, the ferric ions make a coloured complex with xylenol orange in an acidic medium and the intensity of this colour is measured spectrophotometrically. This is directly related to the total amount of oxidant molecule present in the sample. ${ }^{10}$ Superoxide Dismutase (SOD) was measured with help of Caymans superoxide dismutase assay kit, (item number 706002 from Caymen chemical company. 1180 East Ellsworth Road. Ann Arbor, Michigan 48108. USA). Total Antioxidant status (TAS) was measured with help of Caymans antioxidant assay kit, (item number 709001 from Caymen chemical company · 1180 East Ellsworth Road. Ann Arbor, Michigan 48108. USA).

The oxidative stress index (OSI) was calculated from a percent ratio of total oxidant level to the total antioxidant (TAS) level as explained elsewhere. ${ }^{22}$

OSI=[ TOS ( $\mu \mathrm{mol} \mathrm{H}_{2} \mathrm{O}_{2}$ equivalent/L) / TAS ( $\mu \mathrm{mol}$ Trolox equivalent/L) X100

\section{Statistical analysis:}

Results were expressed as mean $\pm \mathrm{SD}$ and these were evaluated using student paired and unpaired $t$ test and $z$ test. $P$ value was considered highly significant if $<0.0001$ and significant if $<0.05$.

\section{Results}

The final study comprised of 30 patients and 60 healthy controls. Table 1 lists the general demographic and clinical characteristics of case group. Controls were age and sex matched and hence not statistically different from study patients (Table 1 ).

Status of enzymatic oxidative stress indicators between cases and controls:

It was observed that Malondialdehyde (MDA) in cases 
was $0.89( \pm 0.32) \mu \mathrm{mol}$ and in controls was $0.42( \pm 0.12)$ $\mu \mathrm{mol}$ This difference was highly significant. $\mathrm{P}<0.0001$. On estimation of Nitric oxide (NO), in cases it was $160.92( \pm 9.93)$ and $\mathrm{mmol}$ and in controls 47.26 ( \pm 10.15$)$ $\mathrm{mmol}$. This difference was also highly significant. $\mathrm{P}<0$. 0001. The level of Superoxide dismutase (SOD) was significantly less in cases $2.43( \pm 1.82) \mu \mathrm{mol}$ compared to controls 5.21( \pm 0.34$) \mu \mathrm{mol}$. (Table 2 ).

Status of oxidative stress indices in cases and controls: Total oxidant status was $34.90 \pm 15.55 \mathrm{mmol}$ in controls and increased in cases $150.06 \pm 44.43 \mathrm{mmol}$. This difference was highly significant, $p$ value was $<0.0001$. On the contrary, total antioxidant status was $1.09 \pm 0.12$ $\mu \mathrm{mol}$ in controls and got decreased in cases, $0.39 \pm 0.26$ $\mu \mathrm{mol}$. This difference was also highly significant, $\mathrm{p}$ value was $<0.0001$. On calculating the oxidative stress index there was highly significant increase in cases, $73.39 \pm 29.98 \mathrm{mmol}$ as compared with controls, $3.15 \pm 1.37 \mathrm{mmol}$ (Table 3).

Baseline comparison of oxidative stress parameters with bacterial load and type of leprosy.

The total oxidant status (TOS), total antioxidant status (TAS), oxidative stress index (OSI) and Malondialdehyde (MDA) levels were decreased in Bacteriological index = 0 in comparison to Bacteriological index $\geq 1$ However, this was not statically significant. The Nitric oxide (NO) and Superoxide dismutase (SOD) were increased in Bacteriological index $=0$ in comparison with Bacteriological index $\geq 1$, And this increase was also not significant.
The total antioxidant status (TAS) and oxidative stress index (OSI) and Malondialdehyde (MDA) levels were decreased in Paucibacillary in comparison to Multibacillary with no statistical significance.

The total oxidant status (TOS), Nitric oxide (NO) and Superoxide dismutase (SOD) were increased in Paucibacillary in comparison with Multibacillary with no significant difference (Table 4).

Table 1: Demographic and clinical characteristics of case group.

\begin{tabular}{|c|c|}
\hline Variables & Cases $(n=30)$ \\
\hline \multicolumn{2}{|l|}{ Gender= n (\%) } \\
\hline Female & $10(33 \%)$ \\
\hline Male & $20(67 \%)$ \\
\hline \multicolumn{2}{|l|}{ Age (\%) } \\
\hline $18-30$ years & $15(50 \%)$ \\
\hline $30-50$ years & $11(37 \%)$ \\
\hline $50-70$ years & $4(13 \%)$ \\
\hline \multicolumn{2}{|l|}{ PB/MB (\%) } \\
\hline PB & $14(47 \%)$ \\
\hline $\mathrm{MB}$ & $16(53 \%)$ \\
\hline \multicolumn{2}{|c|}{ Bacteriological index (\%) } \\
\hline $\mathrm{BI}=0$ & $17(57 \%)$ \\
\hline $\mathrm{BI} \geq 1$ & $13(43 \%)$ \\
\hline \multicolumn{2}{|c|}{ Morphological index\% $(n=13)$} \\
\hline $\mathrm{MI}=0$ & $2(15 \%)$ \\
\hline $\mathrm{MI} \geq 1$ & $11(85 \%)$ \\
\hline \multicolumn{2}{|c|}{ Nerve involvement (\%) } \\
\hline $\mathrm{N} \leq 1$ & $16(53 \%)$ \\
\hline$N \geq 2$ & $14(47 \%)$ \\
\hline
\end{tabular}

Table 2: Status of enzymatic oxidative stress indicators between cases and controls ( $Z$ test).

\begin{tabular}{|c|c|c|c|c|}
\hline Indicator & $\begin{array}{c}\text { Cases } \\
n=30 \\
\text { mean } \pm S D\end{array}$ & $\begin{array}{l}\text { Controls } \\
n=60 \\
\text { mean } \pm S D\end{array}$ & t-test value & P value \\
\hline $\begin{array}{l}\text { Malondialdehyde } \\
\text { (MDA } \mu \mathrm{mol})\end{array}$ & $0.89 \pm 0.32$ & $0.42 \pm 0.12$ & 10.08 & $<0.0001$ \\
\hline $\begin{array}{l}\text { Nitric oxide } \\
\text { (NO mmol) }\end{array}$ & $160.92 \pm 9.93$ & $47.26 \pm 10.15$ & 50.43 & $<0.0001$ \\
\hline $\begin{array}{l}\text { Superoxide dismutase } \\
\text { (SOD } \mu \mathrm{mol})\end{array}$ & $2.43 \pm 1.82$ & $5.21 \pm 0.34$ & 11.49 & $<0.0001$ \\
\hline
\end{tabular}

SD:standard deviation

Table 3: Oxidative stress indicators of leprosy.

\begin{tabular}{|l|c|c|c|c|}
\hline Category & $\begin{array}{c}\text { Cases } \\
\mathbf{N = 2 8}\end{array}$ & $\begin{array}{c}\text { Controls } \\
\mathbf{N = 4 0}\end{array}$ & t-test value & P value \\
\hline Total Oxidant status (TOS mmol) & $150.06 \pm 44.43$ & $34.90 \pm 15.55$ & 18.06 & $<0.0001$ \\
\hline Total antioxidant status (TAS $\mu \mathrm{mol})$ & $0.39 \pm 0.26$ & $1.09 \pm 0.12$ & 13.68 & $<0.0001$ \\
\hline Oxidative stress index (OSI mmol) & $73.39 \pm 29.98$ & $3.15 \pm 1.37$ & 18.21 & $<0.0001$ \\
\hline
\end{tabular}


Table 4: Comparison of oxidative stress parameters with bacterial load and type of leprosy (One way ANOVA test).

\begin{tabular}{|c|c|c|c|c|c|c|c|c|c|c|c|c|}
\hline \multirow[b]{2}{*}{ Variables } & \multicolumn{3}{|c|}{ Gender } & \multicolumn{3}{|c|}{ AGE (Years) } & \multicolumn{3}{|c|}{ Type of leprosy } & \multicolumn{3}{|c|}{ BACTERIOLOGICAL INDEX } \\
\hline & $\begin{array}{l}\text { MALE } \\
(20)\end{array}$ & $\begin{array}{c}\text { FEMALE } \\
\text { (10) }\end{array}$ & $\begin{array}{c}\text { CONTROLS } \\
(60)\end{array}$ & $\begin{array}{c}15-30 \\
(15)\end{array}$ & $>30$ (15) & $\begin{array}{c}\text { CONTROLS } \\
(60)\end{array}$ & PB (14) & MB (16) & $\begin{array}{c}\text { CONTROLS } \\
(60)\end{array}$ & $\mathrm{BI}=0(17)$ & $\mathrm{BI} \geq 1(13)$ & $\begin{array}{c}\text { CONTROLS } \\
\text { (60) }\end{array}$ \\
\hline $\begin{array}{l}\text { MDA } \\
(\mu \mathrm{mol})\end{array}$ & $\begin{array}{c}0.91 \pm \\
0.36 * *\end{array}$ & $\begin{array}{c}0.83 \pm \\
0.21 * *\end{array}$ & $0.42 \pm 0.12$ & $\begin{array}{l}0.820 \pm \\
0.20 * *\end{array}$ & $\begin{array}{c}1.00 \pm \\
0.464 * *\end{array}$ & $0.42 \pm 0.12$ & $\begin{array}{c}0.85 \pm \\
0.29 * *\end{array}$ & $\begin{array}{c}0.97 \pm \\
0.40 * *\end{array}$ & $0.42 \pm 0.12$ & $\begin{array}{c}0.87 \pm \\
0.34 * *\end{array}$ & $\begin{array}{c}0.91 \pm \\
0.34 * *\end{array}$ & $0.42 \pm 0.12$ \\
\hline $\begin{array}{l}\text { NO } \\
\text { (mmol) }\end{array}$ & $\begin{array}{c}158.76 \pm \\
0.41\end{array}$ & $\begin{array}{c}163.50 \pm \\
8.83\end{array}$ & $\begin{array}{c}47.26 \pm \\
10.15\end{array}$ & $\begin{array}{c}158.27 \pm \\
8.74\end{array}$ & $\begin{array}{c}159.78 \pm \\
8.78\end{array}$ & $\begin{array}{c}47.26 \pm \\
10.15\end{array}$ & $\begin{array}{c}162.70 \pm \\
11.30\end{array}$ & $\begin{array}{c}157.90 \pm \\
7.45\end{array}$ & $\begin{array}{c}47.26 \pm \\
10.15\end{array}$ & $\begin{array}{c}160.80 \pm \\
10.80\end{array}$ & $\begin{array}{c}158.24 \pm \\
6.65\end{array}$ & $\begin{array}{c}47.26 \pm \\
10.15\end{array}$ \\
\hline $\begin{array}{l}\text { SOD } \\
(\mu \mathrm{mol})\end{array}$ & $\begin{array}{c}2.03 \pm \\
0.41^{* *}\end{array}$ & $\begin{array}{c}3.23 \pm \\
3.37^{* *}, \#\end{array}$ & $5.21 \pm 0.34$ & $\begin{array}{c}2.09 \pm \\
0.42^{* *}\end{array}$ & $\begin{array}{l}2.46 \pm \\
2.22 * *\end{array}$ & $5.21 \pm 0.34$ & $\begin{array}{c}2.78 \pm \\
2.45^{* *}\end{array}$ & $\begin{array}{c}1.97 \pm \\
0.41^{* *}\end{array}$ & $5.21 \pm 0.34$ & $\begin{array}{c}2.53 \pm \\
2.00 * *\end{array}$ & $\begin{array}{l}1.92 \pm \\
0.43^{* *}\end{array}$ & $5.21 \pm 0.34$ \\
\hline $\begin{array}{l}\text { TAS } \\
(\mu \mathrm{mol})\end{array}$ & $\begin{array}{c}0.44 \pm \\
0.32 * *\end{array}$ & $\begin{array}{c}0.34 \pm \\
0.27 * *\end{array}$ & $1.09 \pm 0.12$ & $\begin{array}{l}0.367 \pm \\
0.28 * *\end{array}$ & $\begin{array}{l}0 . .48 \pm \\
0.33 * *\end{array}$ & $1.09 \pm 0.12$ & $\begin{array}{l}0.34 \pm \\
0.18^{* *}\end{array}$ & $\begin{array}{l}0.47 \pm \\
0.37^{* *}\end{array}$ & $1.09 \pm 0.12$ & $\begin{array}{l}0.38 \pm \\
0.27^{* *}\end{array}$ & $\begin{array}{c}0.48 \\
\pm 0.0 .37 * * \\
\end{array}$ & $1.09 \pm 0.12$ \\
\hline $\begin{array}{l}\text { TOS } \\
\text { (mmol) }\end{array}$ & $\begin{array}{l}161.71 \pm \\
48.04 * *\end{array}$ & $\begin{array}{l}149.26 \pm \\
42.04 * *\end{array}$ & $\begin{array}{c}34.90 \pm \\
15.55\end{array}$ & $\begin{array}{l}155.25 \pm \\
40.07^{* *}\end{array}$ & $\begin{array}{l}166.58 \pm \\
52.93 * *\end{array}$ & $\begin{array}{c}34.90 \pm \\
15.55\end{array}$ & $\begin{array}{l}162.93 \pm \\
45.67 * *\end{array}$ & $\begin{array}{l}157.97 \pm \\
48.04^{* *}\end{array}$ & $\begin{array}{c}34.90 \pm \\
15.55\end{array}$ & $\begin{array}{l}158.67 \pm \\
46.92 * *\end{array}$ & $\begin{array}{l}159.97 \pm \\
47.75 * *\end{array}$ & $\begin{array}{c}34.90 \pm \\
15.55^{* *}\end{array}$ \\
\hline $\begin{array}{l}\text { OSI } \\
\text { (mmol) }\end{array}$ & $\begin{array}{l}79.32 \pm \\
85.56 * *\end{array}$ & $\begin{array}{c}57.43 \pm \\
46.73^{* *}\end{array}$ & $3.15 \pm .37$ & $\begin{array}{c}71.04 \pm \\
89.04 * *\end{array}$ & $\begin{array}{c}79.25 \pm \\
69.15^{* *}\end{array}$ & $3.15 \pm .37$ & $\begin{array}{c}66.81 \pm \\
60.71 * *\end{array}$ & $\begin{array}{c}79.83 \pm \\
89.47^{* *}\end{array}$ & $3.15 \pm .37$ & $\begin{array}{c}60.58 \pm \\
58.68 * *\end{array}$ & $\begin{array}{c}94.39 \pm \\
99.50 * *\end{array}$ & $3.15 \pm .37^{* *}$ \\
\hline
\end{tabular}

highly significant with controls $=* *$, significant with controls $=*$, significant $=$ \#

\section{Discussion}

The present study is a prospective study which includes 60 cases of healthy controls and 30 cases of leprosy patients. In modern era, interest has grown in investigating the role played by reactive oxygen species or oxidative stress in leprosy leprosy by investigating one or more of the oxidant markers like Malondialdehyde (MDA) and antioxidant markers, including SOD, catalase, vitamin E, vitamin C. ${ }^{11-14}$

Lipid peroxidation is involved in pathogenesis of many disease processes when the imbalance occurs between production of reactive oxygen species and protective antioxidant system. Malondialdehyde (MDA) is a marker of lipid peroxidation. ${ }^{15}$ In the present study, MDA was significantly high in serum of leprosy patients ( $p<0.0001$ ) in comparison to healthy controls. Agnihotri N, et al (1995) noticed increased levels of lipid peroxidation levels in mice infected with M. leprae. ${ }^{4}$ Bhadwat VR et al in their study showed increased Malondialdehyde levels in leprosy patients and more so in lepromatous leprosy. ${ }^{16}$

In the present study, the activity of serum enzymatic antioxidant superoxide dismutase (SOD) was highly significantly low in leprosy cases as compared to control group ( $p<0.0001$ ). Previous studies have also reported significant reduction of activity of serum SOD in untreated leprosy patients. ${ }^{19,20}$ Regarding nitric oxide production, we observed that their levels were significantly higher in leprosy patients as compared to healthy controls $(p<0.0001)$. The reason behind it is that Microbial killing of lepra bacilli results in production of free radicals like nitric oxide. ${ }^{21}$ These findings are similar to the study done by Schalcher TR et al who also reported increased production of nitric oxide levels in leprosy patients as compared to healthy controls and no change in nitric oxide levels were seen after treatment with antileprosy drugs ${ }^{11,14}$ It seems that the disease process itself appears to be responsible for the detected nitric oxide increase in the body irrespective of the antileprosytreatment. ${ }^{14}$

Studies have tried to quantify oxidative stress as per evaluating levels of various enzymes and carbonyl proteins. Some of the research analyst reported changes of these markers like Superoxide Dismutase (SOD), Glutathione peroxidase (GPx), Malondialdehyde (MDA), Nitric Oxide (NO), and Catalase. ${ }^{1,12}$ But these studies didn't measure the total oxidative stress unlike our present study. Oxidative stress can be measured by calculating the ratio of total oxidant status (TOS) and total antioxidant status (TAS). ${ }^{10,22}$ In the present study there was a highly significant increase in the total oxidant status in leprosy patients in comparison to healthy controls $(P<0.0001)$ and there was a highly significant decrease in mean total antioxidant status in leprosy in comparison to healthy controls $(P<0.0001)$. This supports the theory that generation of free radicals are involved in the pathogenesis of leprosy. ${ }^{1,13}$

When we measured oxidative stress index(OSI) by ratio of TOS/TAS, Highly Significant increase in the OSI was observed in patients of leprosy as compared to healthy controls ( $p<0.0001$ ). Bhadwat VR et al reported increased oxidative stress by quantifying ratio of (MDA/SOD) in LL leprosy in comparison to TT leprosy. ${ }^{16}$ Abdel-Hafez $\mathrm{HZ}$ et al also reported similar findings. ${ }^{18}$ Jyothi $\mathrm{P}$ et al reported significant elevation in oxidative stress by measuring the ratio of (MDA/ SOD) in MB leprosy. ${ }^{17}$ Hence this study confirms the presence of oxidative stress in leprosy and intervention with antioxidant supplementation may improve the 
total oxidant capacity of the patient by reducing the production of reactive oxygen species(ROS) which in turn improves the oxidative stress in leprosy.

\section{Conclusion}

Our study confirmed the oxidative stress in leprosy with highly significant increase in oxidative stress index in leprosy patients. The enzymatic antioxidant superoxide dismutase (SOD) was reduced in leprosy patients indicating enzymatic stress in leprosy. The drawback in our study was less number of patients

\section{References}

1. Vijayaraghavan R, Paneerselvam C. Erythrocyte Antioxidant Enzymes in Multibacillary Leprosy Patients. Int J Appl Biol Pharm Technol. 2011; 2:409-12.

2. Sheriff DS. Erythrocyte Glutathione Concentration as a Measure of Oxidant Stress in Patients Undergoing Dapsone Therapy. Ann Clin Biochem. 1989;26(2):199-200. https://doi. org/10.1177/000456328902600223

3. Adachi T, Marklund S. Interactions between human extracellular superoxide dismutase $C$ and sulfated polysaccharides. J Bio Chem. 1989;264:(2)8537-41. https://doi. org/10.5935/0305-7518.19950021

4. Agnihotri N, Ganguly NK, Kaur S, Khuller M, Sharma SC, Chaugh KS. Role of reactive oxygen species in renal damage in experimental leprosy. Lepr Rev. 1995;66(3):201-9.

5. DeanRT,ShalinFU,StockerR, DavisMJ.Biochemistry and pathology of radical-mediated protein oxidation. Biochem J. 1997;262(2)9895-901. https://doi.org/10.1042/bj3240001

6. Cerne D, Lukac-Bajalo J. Oxidative stress assays for disease risk stratification. Acta Pharm. 2006;56(1):1-17

7. Ridley DS, Jopling WH. Classification of leprosy according to immunity. A five-group system. Int J Lepr Other Mycobact Dis. 1966;34: 255-73.

8. Pinnell SR. Cutaneous photodamage, oxidative stress, and topical antioxidant protection. J Am Acad Dermatol. 2003;48(1):1-19. https://doi. org/10.1067/mjd.2003.16

9. Granger DL, Anstey NM, Miller WC, Weinberg JB. Measuring nitric oxide production in human clinical studies. Methods Enzymol. 1999;301:49-61. https://doi.org/10.1016/S0076-6879(99)01068-X and that we could not measure the nonenzymatic antioxidants in our patients. Further studies need to be done on a larger scale with estimation of enzymatic, non-enzymatic antioxidants and total oxidative stress in leprosy patients. These findings support a hypothesis that any enzymatic supplementation might have an attractive approach in combating oxidative stress mediated insult during the chronic course of the disease process of leprosy.

Financial disclosure: None.

Conflicts of interest to disclosure: None declared.

10. Erel O. A new automated colorimetric method for measuring total oxidant status. Clin Biochem. 2005;38(12):1103-11. https://doi.org/10.1016/j. clinbiochem.2005.08.008

11. Schalcher TR, Borges RS, Coleman MD, Batista Júnior J, Salgado CG, Vieira JL, et al. Clinical oxidative stress during leprosy multidrug therapy: Impact of Dapsone Oxidation. PLoS One. 2014;9(1): e85712. https://doi.org/10.1371/ journal.pone.0085712

12. Prabhakar MC, Santhikrupa D, Manasa N, Rao OU. Status of free radicals and antioxidants in leprosy patients. Indian J Lepr. 2013;85(1):5-9.

13. Swathi $M$, TagoreR. Study of oxidative stress in different forms of leprosy. Indian J Dermatol. 2015;60(3):321. https://doi.org/10.4103/00195154.156426

14. Schalcher TR, Vieira JL, Salgado CG, Borges $\mathrm{RD}$, Monteiro MC. Antioxidant factors, nitric oxide levels, and cellular damage in leprosy patients. Revista da Sociedade Brasileira de Medicina Tropical. 2013;46(5):645-9. https://doi. org/10.1590/0037-8682-1506-2013

15. Gawe S, Wardas M, Niedworok E, Wardas P. Malondialdehyde (MDA) as a lipid peroxidation marker. Wiad Lek. 2004;57(9-10):453-5.

16. Bhadwat VR, Borade VB. Increased lipid peroxidation in lepromatous leprosy. Indian J Dermatol Venereol Leprol. 2000;66:121-5.

17. Jyothi P, Riyaz N, Nandakumar G, Binitha MP. A study of oxidative stress in paucibacillary and multibacillary leprosy. Indian J Dermatol Venereol Leprol 2008;74:80. https://doi.org/10.4103/03786323.38428

18. Abdel-Hafez HZ, Mohamed EE, Abd-Elghany AA. Tissue and blood superoxide dismutase activity and malondialdehyde level in leprosy. J Eur Acad Dermatol Venereol. 20101;24(6):704-8. https:// doi.org/10.1111/j.1468-3083.2009.03496.x 
19. Sethi NC, Madadi AJ, Bhandari S. Serum zinc, copper, magnesium, proteins and superoxide dismutase in leprosy patients on multidrug therapy - A follow-up study. Indian J Lepr. 1996;68(4):325-33.

20. Reddy YN, Murthy SV, Krishna DR, Prabhakar MC. Oxidative stress and anti-oxidant status in leprosy patients. Indian J Lepr. 2003;75(4):307-16.
21. Valko M, Leibfritz D, Moncol J, Cronin MT, Mazur $\mathrm{M}$, Telser J. Free radicals and antioxidants in normal physiological functions and human disease. Int J Biochem Cell Biol. 2007;39:44-84. https://doi.org/10.1016/j.biocel.2006.07.001

22. Bakir S, Celiksoz A, Celik V, Sari I, Aydin H. Antioxidant-oxidant status in patients with hydatid cyst. Turk J Bioch. 2012;37(1):29-34. 